\title{
What Do I Contribute to Business Communication?
}

\section{Priscilla S. Rogers}

Editorial Board of Business Communication Research and Practice, Univeristy of Michigan, Ann Arbor, MI, USA

Business communication (BC) is a hybrid field. It's undertaken by academics worldwide from a wide variety of disciplines (Locker, 1998) who focus on workplace writing and speaking. As diverse academics in this field, the collegial glue that holds us together consists of our Associations - such as the Association for Business Communication (ABC), the Japan Business Communication Association (JBCA), and the Korean Association for Business Communication (KABC) - and our BC journals (Lowry, Humpherys Malwitz, \& Nix, 2007; Rogers, Campbell, Louhiala-Salminen, Rentz, \& Suchan, 2007), a portfolio that now includes KABC's Business Communication Research and Practice.

$\mathrm{BC}$ is also sustained by our contributions as individual academics. This editorial identifies contributions tied to our academic responsibility, disciplinary commitment, and personal development as individuals. It asks us to consider what we're contributing to nurture $\mathrm{BC}$ and its community and encourages personal introspection by using "your" when describing why various contributions are critical and how to pursue them.

\section{Academic Responsibility}

Individual academic responsibility involves serving BC associations, journals, and colleagues to insure that the field continues to function as a vibrant and credible academic endeavor. Service is critical because BC has no uniform home in academic institutions. Around the world, support for BC in our institutions varies and can fluctuate as administrators change. Indeed, BC has been characterized as an "orphan" field (Hagge, 1986, p. 174). $\mathrm{BC}$ 's viability in academe depends on your willingness to:

1. Serve on $A B C$ Committees to bring your individual expertise into the BC community. Simply select a committee and let its chair know of your interest (https://www.business- communication.org/page/committees).

2. Review Submissions to BC Journals to maintain the academic rigor of $\mathrm{BC}$ publications by helping authors strengthen their submissions and editors formulate their decisions. Reviewing for lesser known journals, such as Business Communication Research and Practice and The Asian ESP Journal, may be particularly helpful. Letting an editor or associate editor know you're willing to review is the first step.

\section{Publish a Book Review that Showcases a Colleague's} Work and/or BC Content to encourage others to use it and publishing companies to value BC contributions. ABC's Business and Professional Communication Quarterly regularly publishes book reviews, for example Day's (2018) review of Kelm and Victor's book on intercultural communication in Brazil.

\section{Nominate a BC Colleague for ABC's Outstanding} Teacher-Scholar Award, Distinguished Member Award, or Rising Star Award to draw attention to the quality of their contributions including from their school administrators (https://www.businesscommunication.org/page/member-awards).

\section{Include "Acknowledgements" in Your Published Articles} to recognize the editors, reviewers, colleagues, and staff who contributed and may cite this recognition when their performance is reviewed.

6. Send Thank You Notes to association leaders, conference speakers, and colleagues who contribute in special ways to support them and build comradery. 
7. Engage First-time Attendees at Conferences to encourage their continued participation and grow our BC community. First-timers are identified by special conference nametags.

8. Get to Know Unfamiliar Conference Attendees during breaks and meals to build your BC network. Consider targeting attendees from different counties and cultures.

\section{Attend Presentations by C.R. Anderson Research Fund} (CRARF) Recipients at ABC's annual international conference to support research that is selected as important for BC by ABC's CRARF Committee and the C.R. Anderson Research Foundation Board. Your feedback could also help these presenters move their research toward publication, a goal they are challenged to achieve when receiving funds.

10. Support CRARF Monetarily as a way to give back to our field. Senior faculty in particular should consider this opportunity and recipients of $\mathrm{ABC}$ award money should consider if they can afford to designate it to CRARF. For details contact Marilyn Buerkens (abcoffice@businesscommunication.org) at $\mathrm{ABC}$ Headquarters.

\section{Disciplinary Commitment}

Disciplinary commitment involves championing research and pedagogy that maintains BC's focus and deepens our understanding of its relevance with new knowledge. Championing our discipline is critical because our various departments and schools have diverse support systems for $\mathrm{BC}$ teaching and research and none of them offer a BC Ph.D. BC's credibility as a rigorous academic discipline depends on your willingness to:

\section{Focus Research on Business Communication (BC)} rather than on corporate, organizational, marketing, or technical communication to deepen our understanding of critical workplace writing and speaking issues comprising the heart of BC. To learn more about BC's focus, consult Du-Babcock's (2014) and Nickerson's (2014) chapters on BC in Bhatia and Bremner's (2014) Handbook of Language and Professional Communication.

12. Ground Research and Teaching in Theory to demonstrate BC's connection to fundamental ways of thinking and acting. Bremner's (2018) description of six theoretical constructs underpinning business writing is one helpful resource.
13. Cite BC Journal Publications in your presentations, working papers, and publications to demonstrate the relevance of your research for our communal dialogue and to bolster our journals' reputations in research repositories, such as the Social Science Research Network (Lowry, et al., 2007; Rogers et al., 2007).

14. Write Literature Review Articles on constructs that are important to workplace writing and speaking. Literature reviews tend to be widely read and are an invaluable resource graduate students and researchers.

15. Write Commentaries on Colleagues' Research to advertise and extend their findings. An apt example is Mayfield and Mayfield's (2019) commentary on Clark, Tan, Murfett, Rogers, and Ang's 2019 study of call center interactions whose authors include $\mathrm{ABC}$ members. The Journal of Business and Technical Communication recently announced an openness to publishing commentaries.

16. Use Analytical Tools Developed by BC Colleagues to validate the tools' while enriching your research and teaching. For example, BC faculty at Singapore's Nanyang Business School and at Helsinki's Aalto University School of Business use the Competing Values Framework (Quinn, Hildebrandt, Rogers, \& Thompson, 1991; Rogers \& Hildebandt, 1993) developed by BC colleagues at the University of Michigan Business School to help MBAs evaluate their workplace communication skills.

\section{Nominate $B C$ Colleagues for ABC's Outstanding Re-} searcher Award to call attention to research that our BC community should treat as foundational and to help the researchers who originated it get promoted (https://www.businesscommunication.org/page/locker).

18. Distribute Publications to Colleagues doing similar work to encourage connectivity in our research. These publications may be your own or those of others that are relevant to our communal conversation.

19. Host Informal Gatherings at Conferences with a small group of colleagues who would benefit from getting to know each other.

20. Use Your Schools' Resources to Advance BC Locally For example, schools with MBA programs have access to the 
essays their new admits wrote for the Graduate Management Assessment Test (GMAT). These essays can be used for oneon-one writing consultations to help new admits assess their managerial writing skills using analytical tools developed by Rogers and Rymer (2001). Other opportunities to advance BC locally are serving as an outside dissertation committee member, volunteering to judge case competitions, and mounting special in-school events, such as faculty-student debates on timely topics or story-telling competitions that call attention to communication skills.

\section{Personal Development}

Personal development involves commitment to learn about $\mathrm{BC}$ continuously. Individual growth is the life blood of our BC community; it enables us to shape and advance our field. BC's communal health depends on your willingness to:

\section{Read Journal Articles and Academic Books Regularly to remain relevant.}

22. Write-up Your Research Focus Periodically to review your progress, discover relationships between your various projects, and consider if you're staying on track. Composing a paragraph describing your research and how it contributes to $\mathrm{BC}$ can be incredibly revealing.

23. Enlist the Advice or Co-authorship of a Senior Faculty Member (perhaps from related field) to build a mentoring relationship from which to learn about available resources, research methods, and academic writing strategies.

\section{Ask Colleagues to Provide Feedback on Working Pa-} pers and Do the Same for Them to obtain candid observations on the $\mathrm{BC}$ content you're developing and to learn from colleagues' developmental work.

\section{Submit a Research Funding Proposal to the C.R. An-} derson Research Fund (CRARF) to subject your research to review by seasoned scholars and to obtain funding for costly activities that can significantly upgrade and validate your research, such as administering blind reviews, obtaining feedback from focus groups, and using evaluative software. Criteria for submitting proposals to CRARF can be found on-line (https://www.businesscommunication.org/page/anderson-applications).

\section{Invite a Colleague to Speak or for a Sabbatical Leave}

at Your School to enrich your local environment and to provide that colleague with evidence of external interest in their work. Support may available if you show your administrators the colleague's vita and describe how their visit contributes to your school.

\section{Stay in Touch with Former Students and Alumni to} find out what's going on in practice. Contacts can be maintained through social media, by responding to email inquiries, and by arranging meetings for afternoon tea or meals when traveling for conferences, work, or fun.

Whether you are new to $\mathrm{BC}$ or have decades of experience, it's likely that reviewing this list of contributions revealed ways you can do more going forward. As a highly-diverse international community, pursuing our academic responsibilities, disciplinary commitment, and personal development as individual contributors is imperative to maintain the viability, rigor, and health of our field. Indeed, our individual diversity is our communal strength when we enlist it to enrich BC.

\section{References}

Bhatia, V., \& Bremner, S. (2014). The routledge handbook of language and professional communication. London, UK: Routledge.

Bremner, S. (2018). Workplace writing: Beyond the text. New York, NY: Routledge.

Clark, C. M., Tan, M. T., Murfett, U. M., Rogers, P. S., \& Ang, S. (2019). The call center agent's performance paradox: A mixed-methods study of discourse strategies and paradox resolution. Academy of Management Discoveries, 5(2), 152-170.

Day, C. R. (2018). The 7 keys to communicating in Brazil: An intercultural approach. Business and Professional Communication Quarterly, 81(2), 272-274.

Du-Babcock, B. (2014). Business communication: A revisiting of theory, research, and teaching. In V. Bhatia \& S. Bremner (Eds.), The routledge handbook of language and professional communication (pp. 68-84). London, UK: Routledge.

Hagge, J. (1986). Business communication, the orphaned discipline: A historical review of business communication teachers' perceptions of their field's place in the college curriculum. Proceedings of the 51st ABC International Convention (pp 168-177). Los Angeles, CA.

Locker, K. O. (1998). The role of the Association for Business Communication in shaping business communication as an academic discipline. The Journal of Business Communication, 35(1), 14-49.

Lowry, P. B., Humpherys, S. L., Malwitz, J., and Nix, J. (2007). A scientometric study of the perceived quality of business and tech- 
nical communication journals. IEEE Transactions on Professional Communication, 50(4), 352-378.

Mayfield, J., \& Mayfield, M. (2019). A commentary on "the call center agent's performance paradox: A mixed-methods study of discourse strategies and paradox resolution. Academy of Management Discoveries, 5(2), 205-206.

Nickerson, C. (2014). Business communication. In V. Bhatia \& S. Bremner (Eds.), The routledge handbook of language and professional communication (pp. 50-67). London, UK: Routledge.

Quinn, R. E., Hildebrandt, H. W., Rogers, P. S., \& Thompson, M. P. (1991). A competing values framework for analyzing presentational communication in management contexts. The Journal of Business Communication, 28(3), 213-232.

Rogers, P. S., Campbell, N., Louhiala-Salminen, L., Rentz, K., \& Suchan, J. (2007). The impact of perceptions of journal quality on business and management communication academics. The Journal of Business Communication, 44(4), 403-426.

Rogers, P. S., \& Hildebrandt, H. W. (1993). Competing values instruments for analyzing written and spoken management messages. Human Resource Management Journal, 32(1), 121-142.

Rogers, P. S., \& Rymer, J. (2001). Analytical tools to facilitate transitions into new writing contexts: A communicative perspective. The Journal of Business Communication, 38(2), 112-152.

Priscilla S. Rogers

Management Communication and Global MBA Program, University of Michigan Ross School of Business, 5th Floor R5492, Ann Arbor, MI, 48109-1234, USA Tel: +1-734-665-3396, E-mail: psr@umich.edu 